\title{
[SUFFER THE SONS-OF-GUNS TO COME UNTO ME.]
}

Suffer the sons-of-guns to come unto me.

Plum-eyed, queasy Joes, them oral-breathing machines.

My heart is greased

all over with God's lard

to squeeze through the eye of a camel.

It was a golden evening.

We turned the corner at Sunset Road, \& there,

a landmark:

Two white birdhouses jammed in the earth at angles

beside a stone-

cold fox.

We were all such (lawn) statues once:

chiseled visages. Beveled noses.

At birth, our bodies were gifted w/ birds

$\&$ at death, they broke from our ribs \& clattered

westward. 